\title{
PARENTAL ENGAGEMENT ON CHILDREN CHARACTER EDUCATION: THE INFLUENCES OF POSITIVE PARENTING AND AGREEABLENESS MEDIATED BY RELIGIOSITY
}

\author{
Raden Rachmy Diana ${ }^{1,3 *}$, Muhammad Chirzin ${ }^{1}$, Khoiruddin Bashori $^{2}$, \\ Fitriah M. Suud ${ }^{3}$, Nadea Zulfa Khairunnisa ${ }^{4}$ \\ ${ }^{1}$ Universitas Islam Negeri Sunan Kalijaga, Indonesia \\ ${ }^{2}$ Universitas Ahmad Dahlan, Indonesia \\ ${ }^{3}$ Universitas Muhammadiyah Yogyakarta, Indonesia \\ ${ }^{4}$ Universitas Gadjah Mada, Indonesia \\ *e-mail : raden.diana@uin-suka.ac.id
}

\begin{abstract}
Parents have an important role in introducing character education to children. Positive parenting and agreeableness are considered to have essential influences on parent engagement in children's character education mediated by religiosity. This study aimed to examine the effects of positive parenting and agreeableness towards parental engagement in character education with religiosity as the mediator. Data were obtained using five instruments, namely the parental engagement scale, agreeableness scale, religiosity scale, Islamic knowledge test items, and the positive parenting scale. The population of this research was the parents of students of Muhammadiyah elementary schools located in the Special Region of Yogyakarta, Indonesia. By cluster random sampling technique, the study involved 210 parents. The collected data were analyzed using the SEM technique. The results of this study show that: (1) there was a significant relationship between positive parenting and agreeableness on parental engagement, (2) religiosity worked as a mediator of the relationship between positive parenting and agreeableness in parental engagement, and (3) religiosity worked better as the mediator of agreeableness than positive engagement. It was concluded that the correlation between agreeableness and parental engagement would not be formed without religiosity as a mediator.
\end{abstract}

Keywords: agreeableness, character education, parental engagement, positive parenting, religiosity.

\section{KETERLIBATAN ORANG TUA DALAM PENDIDIKAN KARAKTER ANAK: PENGARUH PENGASUHAN POSITIF DAN KEPRIBADIAN AGREEABLENESS YANG DIMEDIASI OLEH RELIGIOSITAS}

Abstrak: Orang tua memiliki peran penting dalam menanamkan pendidikan karakter kepada anak. Pengasuhan positif dan kepribadian agreeableness dianggap memiliki pengaruh penting terhadap keterlibatan orang tua dalam pendidikan karakter anak melalui religiositas. Penelitian ini bertujuan untuk melihat pengaruh pengasuhan positif dan kepribadian agreeableness terhadap keterlibatan orang tua dalam pendidikan karakter melalui mediasi religiositas. Data diperoleh dengan menggunakan lima instrument, yaitu skala keterlibatan orang tua, skala agreeableness, skala religiositas, tes pengetahuan Islam, dan skala pengasuhan positif. Populasi penelitian ini adalah orang tua siswa Sekolah Dasar Muhammadiyah di Kota Yogyakarta, Indonesia. Dengan teknik cluster random sampling, penelitian melibatkan 210 responden. Data dianalisis menggunakan teknik SEM. Hasil penelitian menunjukkan bahwa: (1) terdapat hubungan yang signifikan antara pengasuhan positif dan agreeableness terhadap keterlibatan orang tua, (2) religiositas berperan sebagai mediator hubungan antara pengasuhan positif dan agreeableness terhadap keterlibatan orang tua, dan (3) fungsi mediasi religiositas lebih tinggi pada agreeableness dibandingkan dengan pengasuhan positif. Dapat disimpulkan bahwa hubungan antara agreeableness terhadap keterlibatan orang tua tidak akan terbentuk tanpa religiositas sebagai mediator.

Kata Kunci: kepribadian agreeableness, pendidikan karakter, keterlibatan orang tua, pengasuhan positif, religiositas. 


\section{INTRODUCTION}

Parents have an important role in children's education both at home and at school, especially in teaching positive behavior and life values (Sokip, Akhyak, Soim, Tanzeh, \& Kojin, 2019). Bandura \& Thornberry stated that parents have an important role to build connectedness with their child (Muwaga, Nashori, \& Sholeh, 2020). Suud, Chaer, \& Setiawan (2020) also argue that one of the students' external motivations in learning comes from their parents. Therefore, parents need to seriously engage in supporting children's education and success (Manzon, Miller, Hong, \& Khong, 2015). Through engagement in child's education, parents can support their children, such as strengthen relationship with child, provide learning support, and instill character values (Saxena \& Saxena, 2020; Wong et al., 2018). The engagement of parents is known in psychology as parental engagement. Parental engagement refers to the positive and active engagement of parents in students' academic and social lives (LaCroix, 2014).

Parental engagement refers to the beliefs, attitudes, and activities of parents who support children to learn from birth to adulthood both at home, school, and in the community (Weiss, Kreider, Lopez, \& Chatman-Nelson, 2010). Parental engagement is shown by great expectations and respect for children, reading together, dialogue between parents and children, providing a positive environment for homework, providing an environment which stimulates cognitive development, providing support for children's emotional and social well-being, parent and teacher communication (Ahmedi, 2019), and engagement in the school community (Fox \& Olsen, 2014). Effective parent-child communication and partnership play an important role to engaged in character education both at home and at school (Wuryandani, Maftuh, Sapriya, \& Budimansyah, 2014; Suriansyah \& Aslamiah, 2015). Character education can help children to develop personal characters that are important for their future (Sukendar, Usman, \& Jabar, 2019; Komalasari \& Pardjono, 2015).

Parental engagement in a child's education is in line with the child's development. When children are very young, parents show high engagement. This is indicated by the active engagement of parents in their children's preschool education. As the child grows, parental engagement in the child's education decreases. Indonesian development and education psychologist, Setiono (2011) revealed that in recent years, there has been a phenomenon of increasingly high handover of children's educational responsibilities to schools, accompanied by declining parental engagement (Diana, Chirzin, \& Bashori 2019).

Some factors that are thought to play an important role in parental engagement in children's education include positive parenting (Weaver, Weaver, Loux, Jupka, Lew, \& Sallee, 2019), personality trait, and religiosity (Meyer, Fleckenstein, Retelsdorf, \& Köller, 2019). Positive parenting, which a person acquires from parents, influences the engagement of individuals in the character education of their children (Papalia, Olds, \& Fieldman, 2008). Positive assessment of individuals of both parents will help them to be largely involved in taking care of their children. The positive experience of gaining parental care is also a provision for individuals to care for their children in future (Edobor \& Ekechukwu, 2015). Research by Juhari, Yaacob, \& Talib (2010) revealed that positive parenting in the past from one's parents, in this case the father himself, makes individuals involved in the education of their children.

Parental personality is the other factor that influences parental engagement in children's education. The type of personality suspected to be involved in children's education is agreeableness trait (Cheng, Green, Chapman, Treglown, \& Furnham, 2017). Someone who has a high agreeableness score is described as someone who likes to help, likes to forgive, and is merciful (Costa \& McCrae, 1997). With the characteristics described above, it is likely that someone who has high agreeableness will be willing to be deeply involved in the efforts to develop themselves and in their children's education (Huver, Otten, Vries, \& Engels, 2010; El-Hilali \& Al-Rashidi, 2015).

In addition to external factors such as positive parenting and internal personality traits, internal religiosity also influences parental engagement in children's education (Guo, 2018). Religiosity can be known from ideology, rituals, religious practice, religious experience, and religious knowledge. Islamic religiosity can be known from aqidah, worship, morals, ihsan and religious knowledge that belongs to 
individuals (Ancok \& Nashori, 2000). When individuals understand, behave positively, and behave according to the precepts of the religion they believe in, they will be actively involved in their children's education. Religiosity affects how parents act towards their children (Setoh, Santos, Zhao, Zhang, Heyman \& Lee, 2020). Parents who are religios are expected to be engaged in character education for their children (Sokip et al., 2019). Furthermore Decker, Thruston, Howell, Hasselle, \& Kamody (2021) also argued that faith is considered to be able to help individuals face life's obstacles. In terms of parenting, faith can help parents to be more engage in children's education.

Religiosity is influenced by several factors. Positive parenting that individuals receive from their parents in the past and personality is considered to be important in influencing religiosity. Munir \& Malik (2020) show that parental care can affect individual religiosity. Individuals who receive positive parenting are more likely to develop intrinsic religious orientation through secure attachment from their parents. In addition, religiosity is also influenced by individual personality factors. Agreeableness and extraversion are positively correlated with religiosity (Szcześniak, Sopińska, \& Kroplewski, 2019).

The discussion about how personality influences religiosity has become an important topic for the psychological research of religion (Aghababaei, 2014; Ferrari, 2017). Before the 1980s, there had been many studies published on the relationship between religiosity and Eysenck's three factor model of personality (Eysenck, 1998). Nevertheless, in recent years more researcher has started using the Big Five personality to explain the relationship between personality and religiosity. Saroglou (2002) found that religiosity was positively related to agreeableness, consiusness, extraversion, and openess personality trait and was negatively related to neuroticism. Likewise, Szcześniak et al. (2019) provided evidence that agreeableness was positively associated with religiosity. However, some studies have shown inconsistent results. Khoynezhad, Rajaei, \& Sarvarazemy (2012) show that religiosity have a positive relation with personality. Also, personality is not a predictor of religiosity.
Summarizing the various expert views and various research results, this study intends to propose a new theoretical model of parental engagement in children's character education. This initial model was then developed by involving the religiosity variable. Juhari et al. (2010) suggested the inclusion of religiosity as a predictor of parental engagement in children's education. What was suggested by Juhari et al. (2010) was included in a new model that would be known through this research.

Based on the aformentioned explanation, it can be seen that parental engagement is influenced by the complex relationship of several variables rather than bivariate simple relationship. Much of the previous studies have discussed about the parent engagement in parenting or education in general. This study focuses on parental engegement in children's character education. In addition, research on how the dynamics of the role of agreeableness, positive parenting, and religiosity affect parental engagament has not been studied before. The purpose of this study is to examine the theoretical model of the influence of positive parenting and agreeableness personality towards parental engagement in children's character education through the mediation of religiosity.

\section{METHODS}

This study is quantitative approache, to examine the theoretical model of the influence of positive parenting and agreeableness personality towards parental engagement in children's character education through the mediation of religiosity.

\section{Population and Sample}

The population of this study is the parents of Muhammadiyah elementary school students in the city of Yogyakarta, Indonesia. This school is known as a moderate islamic school that follow the ideology of Muhammadiyah. The cluster random sampling technique was carried out by selecting six sub-districts from a total of 14 sub-districts in the city of Yogyakarta. Based on the provisions of cluster random sampling, the minimum number of units, in this case the sub-district unit, is two sub-districts. In this study, 6 schools were randomly selected as research locations. The number of samples from each school can be seen in Table 1 . 
Table 1. Population and Sample Data

\begin{tabular}{clcc}
\hline No. & Sub-distric & Population & Sample \\
\hline 1. Mantijeron & 527 & 28 \\
2. Umbulharjo & 2.802 & 30 \\
3. Pakualaman & 497 & 23 \\
4. Ngampilan & 1706 & 44 \\
5. Wirobrajan & 1135 & 35 \\
6. Tegalrejo & 785 & 50 \\
\hline & Total & 7.452 & 210 \\
\hline
\end{tabular}

\section{Data Collection Technique}

This study used a questionnaire to measure several variable namely the scale of parental engagement, the scale of religiosity, the scale of positive parenting, and the scale of the nature of agreeableness. The aspects of each variables can be seen in Appendix 1, 2, 3, and 4, sequentially. Data were collected by distributing questionnaires directly to research respondents. The validity of this questionnaire consisted of content validity and construct validity. The validity of content is obtained from the judgment of the relevant experts, which is referred to as expert judgment. Meanwhile, the construct validity used confirmatory factor analysis (CFA).

The parental engagement scale was arranged by the researchers by referring to the construct of Fox and Olsen's parental engagement theory (Fox \& Olsen, 2014). Thirty six items were declared valid in this study with a total item moving correlation coefficient between $.311-.826$ and an alpha coefficient of .931 . According to Kline (2015) the coefficient with a value above $.80-.90$ is called very good. Based on the result of validity construct, the CFA result show that one aspect of parental engegement is excluded because it does not show valid results, namely the aspect of reading together. Thus, there are seven aspects of parental involvement with the loading factor for each aspect of parental involvement obtained a value of $>.05$, which means that these aspects are valid

To measure religiosity, a scale of religiosity and a test of Islamic religious knowledge is used. This instrument is modified by the author based on the religiosity scale proposed by Nashori (2010) which refers to the construct of religiosity theory according to Ancok \& Nashori (2000). This religiosity scale is to reveal the dimensions of belief, religious practice, good deeds, and religious experience. From a scale consisting of thirty four items, it is known that the total item correlation coefficient moves between .315 -.782 , and the alpha coefficient of the measuring instrument is .867 . Furthermore, the religious knowledge test consisting of eleven items has a total item correlation coefficient of moves between $.349-.576$. Based on the CFA results, the loading factor shows a value of $>.05$, which means that all aspects of religiosity are valid

To uncover the nature of agreeableness, a scale of agreeableness is used based on the construct of McCrae and Costa's theory (McCrae \& Costa 2003). The scale of agreeableness compiled by Nashori (2010) is intended to uncover six facets, namely tendermindedness, modesty, compliance, altruism, straightforwardness, and trust. The scale has a total item correlation coefficient of .336 .514 and an alpha coefficient of .743. Based on the CFA test, aspects that are declared valid valid are aspect tender-mindedness and straightforwardness with loading factor obtained a value of $>.05$. In addition, from a total of eleven items, there were three items were declared valid so that agreeableness is called a single construct which is based on three items.

A positive parenting scale was arranged by the researcher based on the construct of Eanes's theory. There are five aspects of positive parenting, namely attachment, respect, proactivity, empathy, and positive discipline (Eanes, 2016). The scale consisting of thirty four items has a total item correlation coefficient of .308 - .703, and an alpha coefficient of .897 . Based on the CFA results, the loading factor obtained a value of $>.05$, which means that all aspects of positive parenting are valid.

\section{Data Analysis}

To examine the effect of positive parenting and agreeableness personality on parental engagement mediated by religiosity, this study used the SEM AMOS model, $t$-test, and Anova. The Structural Equation Modeling (SEM) is used to perform measurement models and structural equation models simultaneously. The measurement model was calculated by using confirmatory factor analysis (CFA) on the latent constructs of the research variables. 


\section{Theoretical Models and Hypothesis}

The hypotheses in this study are: a) Major Hypotheses: The theoretical model of the effect of positive parenting and agreeableness through religiosity mediators on parental engagement is fit with empirical data. b) Minor Hypothesis 1) There is a significant positive influence by religiosity on parental engagement; 2) There is a significant positive effect by positive parenting on parental engagement; 3) There is a significant positive effect by positive parenting on religiosity; 4) There is a significant positive effect by agreeableness on parental engagement; 5) There is a significant positive effect of agreeableness on religiosity. Figure 1 is presented the reseacrh framework.

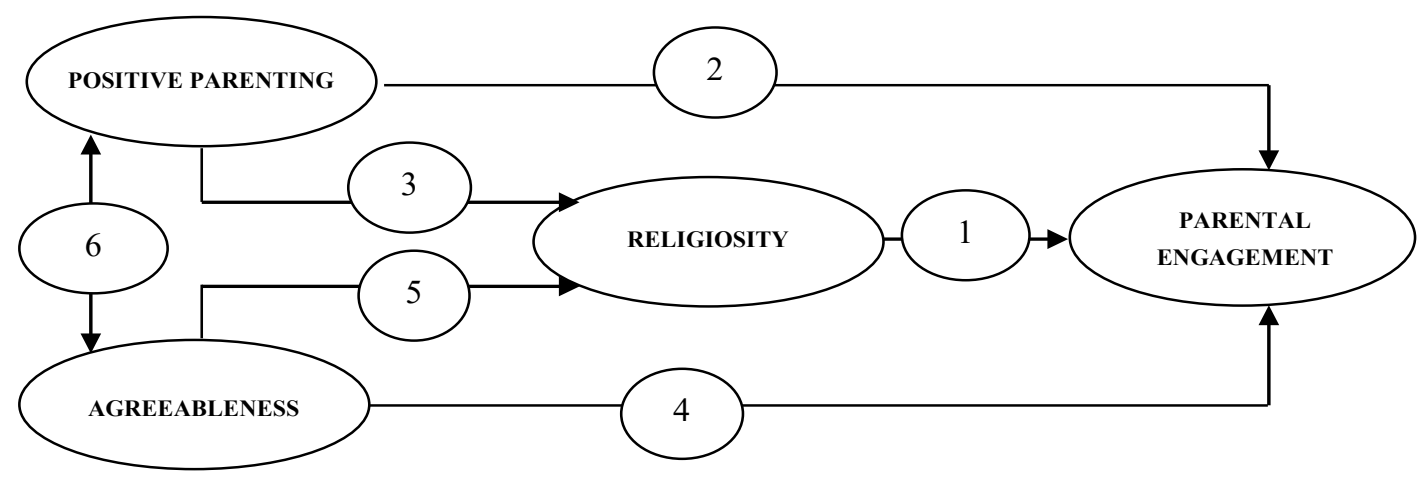

Figure 1. Research Framework

\section{FINDINGS AND DISCUSSION Findings}

The research hypothesis proposed is a model of the effect of positive parenting and agreeableness on parental engagement through religiosity mediators supported by empirical data. Based on the Confirmatory Factor Analysis test of the variables in this study, the following results were obtained.

\section{Major Hypothesis Test Result}

The major hypothesis of the research proposed is a model of the effect of positive parenting and agreeableness personality on parental engagement through mediators of religiosity, which is fit, meaning that it is supported by empirical data. Figure 2 and Table 2 show the result of SEM-AMOS version 22.0.

Based on the Table 2, it can be concluded that the major hypothesis of this study, namely the positive parenting effect model and agreeableness personality on parental engagement through religiosity mediators, has the accuracy of the model that is fit with empirical data based on four parameters standards set by the expert. Thus, all independent variables (positive parenting and agreeableness) correlate to the dependent variable (parental engagement). Secondly, religiosity acts as a mediator of positive parenting and agreeableness towards parental engagement. Thirdly, the mediating function of religiosity is higher in agreeableness than in positive parenting. And lastly, correlation of agreeableness to parental engagement will not be formed without religiosity as a mediator.

Table 2. Goodness of Fit Indices

\begin{tabular}{lll}
\hline Parameter & Score & Criteria \\
\hline$\chi^{2}$ & 941.751 & There are no conditions ${ }^{\mathrm{a}, \mathrm{b}, \mathrm{c}, \mathrm{d}}$ \\
$p$ & $<.01$ & There are no conditions \\
$\mathrm{a}^{\mathrm{a}, \mathrm{b}, \mathrm{c}, \mathrm{d}}$ \\
$\chi^{2} / d f$ & 1.290 & $<2^{\mathrm{a}}$ \\
TLI & .911 & $>.9^{\mathrm{a}, \mathrm{b}, \mathrm{c}}$ \\
CFI & .917 & $>.9^{\mathrm{a}, \mathrm{b}, \mathrm{c}}$ \\
GFI & .911 & $>.9^{\mathrm{a}, \mathrm{b}, \mathrm{c}}$ \\
AGFI & .798 & $>.9^{\mathrm{a}, \mathrm{b}, \mathrm{c}}$ \\
RMSEA & .037 & $<.08^{\mathrm{a}, \mathrm{b}, \mathrm{c}, \mathrm{d}}$ \\
\hline
\end{tabular}

Notes: ${ }^{\mathrm{a}}=$ Goodness of fit criteria according Ghazali (2017); ${ }^{b}=$ Goodness of fit criteria according Furr \& Bacharach (2013); ${ }^{c}=$ Goodness of fit criteria according $\mathrm{Hu} \&$ Bentler (1995); ${ }^{\mathrm{d}}=$ Goodness of fit criteria according Forza \& Filippini (1998)

\section{Minor Hypothesis Test Results}

The minor hypothesis test is carried out summarized in the Table 3. 


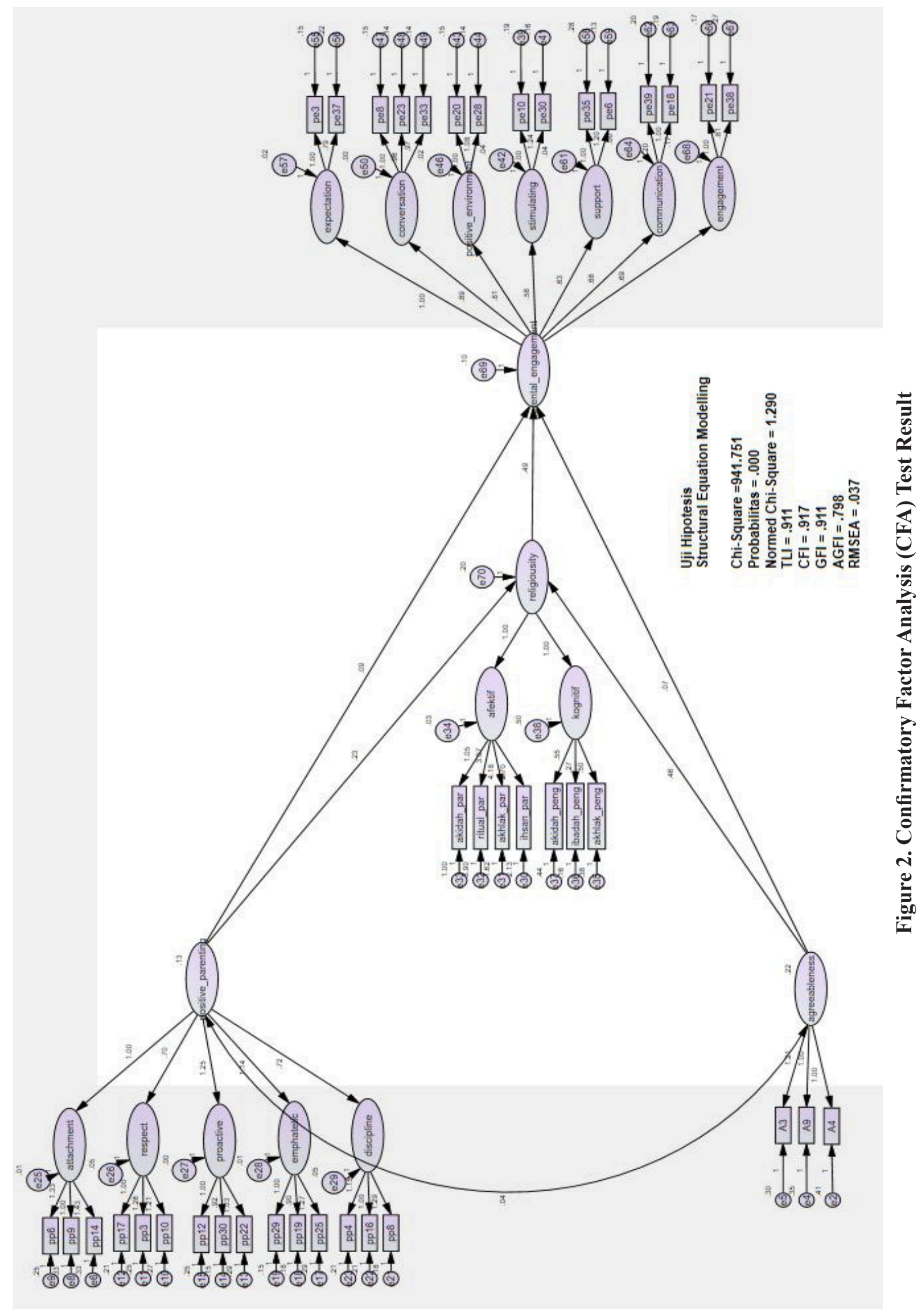


Table 3. Coefficient of Effect among Variables

\begin{tabular}{lll}
\hline Direct Effect & Beta & Note \\
\hline 1. Religiosity $\rightarrow$ Parental Engagement & $.597^{* *}$ & Accepted \\
2. Positive Parenting $\rightarrow$ Parental Engagement & .078 & Rejected \\
3. Positive Parenting $\rightarrow$ Religiosity & $.158^{*}$ & Accepted \\
4. Agreeableness $\rightarrow$ Parental Engagement & -.080 & Rejected \\
5. Agreeableness $\rightarrow$ Religiosity & $.423^{* *}$ & Accepted \\
\hline Indirect Effect & Beta & Note \\
\hline 6. Positive Parenting $\rightarrow$ Religiousity $\rightarrow$ Parental Engagement & $.094^{*}$ & Accepted \\
7. Agreeableness $\rightarrow$ Religiousity $\rightarrow$ Parental Engagement & $.252^{*}$ & Accepted \\
\hline Note: ${ }^{*}=<05 *^{* *}=<01 ; 1-$ tailed & &
\end{tabular}

Note: ${ }^{*}=<.05 ;{ }^{* *}=<.01 ; 1$-tailed

Based on the results of the hypothesis test, it can be concluded that: 1) There is a significant positive effect by religiosity on parental engagement; 2) There is no significant positive effect by positive parenting on parental engagement; 3) There is a significant positive effect by positive parenting on religiosity; 4) There is no significant positive effect by agreeableness on parental engagement; 5) There is a significant positive effect of agreeableness on religiosity; 6) positive parenting can affect parental engagement through mediation of religiosity; and 7) agreeableness can affect parental engagement through mediation of religiosity. The mediating function of religiosity was higher in agreeableness than positive parenting.
The next finding from this study is the contribution of aspects and dimensions to the research variables as shown in Table 4. Based on the results of analysis, it can be concluded that: a) In the dimensions of religiosity, it shows that the dimensions of moral $($ sig $=.000)$ and ihsan $($ sig $=.005)$ have a correlation with parental engagement, with an effective contribution of $27.93 \%$ of moral and $8.51 \%$ of ihsan; b) In positive parenting aspects, it shows that discipline has a correlation $(\mathrm{sig}=.047)$ to parental engagement with an effective contribution of $3.96 \%$; c) The Agreeableness dimension has a correlation (sig $=.004)$ on parental engagement with an effective contribution of $5.51 \%$; d. The total effective contribution of all aspects or dimensions to parental engagement is $45.91 \%$.

Table 4. Contribution of Every Aspect to Parental Engagement

\begin{tabular}{clcccc}
\hline No. Aspect & $\boldsymbol{B}$ & $\begin{array}{c}\text { Sig. } \\
\text { (1-tailed) }\end{array}$ & $\begin{array}{c}\text { Contribution of } \\
\text { Effective }\end{array}$ & $\begin{array}{c}\text { Total } \boldsymbol{R} \text { - } \\
\text { Square }\end{array}$ \\
\hline 1. Aqidah & -.16 & .257 & $-.78 \%$ & \\
2. Ritual & -.06 & .309 & $-1.15 \%$ & \\
3. Moral & .90 & .000 & $27.93 \%$ & \\
4. Ihsan & .44 & .005 & $8.51 \%$ & \\
5. Knowledge of aqidah & .03 & .466 & $-.01 \%$ & \\
6. Knowledge of worship & -.61 & .168 & $-.15 \%$ & \\
7. Knowledge of moral & -.43 & .142 & $-.20 \%$ & $45.91 \%$ \\
8. Attachment & -.34 & .447 & $-.20 \%$ & \\
9. Respect & .30 & .091 & $.27 \%$ & \\
10. Proactive & .02 & .472 & $.11 \%$ & \\
11. Empathetic & .00 & .496 & $.02 \%$ & \\
12. Discipline & .41 & .047 & $.96 \%$ & \\
13. & Agreeableness & .43 & .004 & $5.51 \%$ & \\
\hline
\end{tabular}

Note: 1-tailed is calculated because the direction of the influence must be positive according to the hypothesis, so the significance uses one direction 


\section{Discussion}

The purpose of this study is to examine the model of the influence of positive parenting and agreeableness trait on parental engagement in children's education through religiosity in elementary schools. The results of this study indicated that the model is fitted with the empirical data. It means that positive parenting and agreeableness influence the engagement of parents through their religiosity. Positive parenting and agreeableness foster and develop individual religiosity and produce individuals who become engaged in their children's education.

The results of this study found empirically what was previously suggested by Juhari et al. (2010). Juhari et al. (2010) found that positive parenting was a predictor of parental engagement in children's education. The results of this study also support findings from Bouakaz \& Persson (2007) and Schneider \& Arnot (2018) that parental engagement in children's education is influenced by the main positive parenting factors received by these parents.

The results of this study do not fully support the findings by Huver et al. (2010). Their research found that agreeableness is a predictor of parental engagement in children's education. In this study, it has not been found that agreeableness is significantly a predictor of parental engagement in children's education. Research findings show that to be a predictor of parental engagement in children's education, agreeableness must go through an intermediary of religiosity. A detailed explanation of the research findings is as follows:

First: The effect of positive parenting on parental engagement in children's education. The results of this study support the results of previous studies by Juhari et al. (2010) and Bouakaz \& Persson (2007) that the perception of the role of parents in educating children has a major influence on the engagement of parents in childcare.

Someone's experience in childhood will affect his engagement in childcare in future. As explained by behavioral psychologists (behaviorism), what is done by the role model (parents) will be imitated by individuals. It was also mentioned by Monks, Knoers, \& Haditono (2014) that in the process of growth and development, individuals learn about social problems from the models surround them. If parents as models take care of their children with attention and affection, then the children will replicate these natures (Meyers, Domitrovich, Dissi, Trejo, \& Greenberg, 2019; Yamamoto, Matsuda, Nagata, Dan, \& Hiraki, 2019). The child will then play the role of parents by drawing positively from the parenting process carried out by their parents towards them. Besides, a positive experience of obtaining parental care also makes provisions for individuals to care for their children in future (Leathers, Spielfogel, Geiger, Barnett, \& Voort, 2019)

Among the five positive aspects of parenting the most significant influence on parental engagement in children's education is attachment (Juffer, Bakermans-Kranenburg, \& van IJzendoorn, 2017), empathy (Perez-Albeniz $\&$ de Paul, 2004), and positive discipline. From the point of view of attachment, the biggest factors in a child's parents' engagement in the child's education are the child's perception of the parents as people they can form positive longterm relationships with, the child's perception of the parents as people who can brighten the child's heart, and the child's perception of the parents as people who can influence the child to rise from failure (Munir \& Malik, 2020).

Furthermore, from the point of view of empathy, the next biggest contributor to positive care is the child's perception of the parents as people who can understand the child's needs, empathize with the child and allow freedom with limitations. From the perspective of positive discipline, the most significant contributing factor to an individual's parents' engagement in the individual's education is the individual's perception of the parents as people who control the individual, teach new skills to the individual, and help the individual correct their mistakes and find solutions.

Second: The effect of agreeableness personality on parental engagement in children's education. The results of the study do not fully support the research results of Huver et al. (2010). Their research results revealed that the agreeableness trait influences parental engagement in children's education. However, the results of this study do not support their findings. Instead, it was found that the nature of agreeableness trait does not fully result in the engagement of the individual in their children's 
education.

The results show that parental engagement in children's education is not only contributed by personality factors, but also the nature of agreeableness. It turns out, not automatically, that people who have the quality of agreeableness are willing to be involved in their children's education (Shodiq, Syamsudin, Madjid, \& Alam, 2019). The special nature of the heart, in predicting participation in children's education, only occurs in collaboration with high enough individual religiosity.

Among the six aspects of the nature of agreeableness, two aspects make the most significant contribution, namely straightforwardness and tender-mindedness. Straightforwardness is characterized by honest and sincere attitudes and behavior (Suud, Madjid, \& Sutrisno, 2019) in dealing with others. Meanwhile, tender-mindedness is described by caring for others, which will be directed primarily to feelings of sympathy in making judgments and forming attitudes.

Third: The role of religiosity on parental engagement in children's education. The results of this study prove the truth of the research suggestions by Juhari et al. (2010) and findings from Sokip et al. (2019). They reveal that religiosity plays a positive role in the engagement of parents in the education of their children. The results of this study show the fact that individuals who adhere to good religiosity will understand that they have a God-given mandate to always care for and be involved in their children's education.

Religion has various important roles for individuals; in this case the engagement of parents in children's education. It was expressed by Jalaluddin (2008) that religion plays a role in motivating individuals to carry out meaningful activities. If faith commands individual to do something, and the individual carries out the religious orders, then the individual is obedient. In order to obey what religion commands, individuals become excited about carrying out certain activities (Decker et al., 2021).

If individuals understand, behave positively, and obey the religion they believe in, then they will be actively involved in the education of their children. Muslims are motivated to participate intensively in educating their children because, by educating their children, they will get the reward. Parental engagement in children's education is demonstrated by setting an example for children, giving direction to children, providing emotional support, and providing facilities that support children in their achievements (Nashori, 2010).

Also, the function of religion is to control individual behavior so that, in turn, individuals are willing to be involved in childcare. Religion makes individuals careful to avoid evil. Muslims realize that one of the tasks they carry is to distance themselves and their families from damage in the hereafter. The holy verses of the Al-Qur'an command: "Guard yourself and your family from the fires of hell" (QS at-Tahrim 66 verse 6). The way to take care of the family is as instructed by the Prophet Muhammad: "You forbid anything that God forbids you, and you command what God commands you".

Among the five aspects or dimensions of religiosity, the element which has the most significant influence on parental engagement in children's education is the aspect of morals or charity. The moral dimension is marked by several indicators, namely helping others, discipline/obedience to applicable regulations, being severe in learning/work, making a lawful choice, honesty (Suud \& Subandi, 2017), trust (being responsible and trustworthy), respect for people, istiqomah (consistency), steadfastness (not taking bribes), defending the oppressed, and frugality.

Fourth: The effect of agreeableness on religiosity. The results of this study support the findings of previous psychologists. The results of this study support the results of Szcześniak et al. (2019) and Saroglou \& Fiasse (2003) who discovered that the agreeableness that exists in an individual would affect his religiosity.

Religious experts and psychologists believe that humans have a definite origin. Spiritual experts believe humans have an innate quality called fitrah (Aziz, 2015). Shihab interprets fitrah as "innate from birth" (Shihab, 1996). It has been further revealed by Shihab that humans have the potential to do good rather than do evil. In summary, it is said that humans have positive innate attributes of agreeableness.

In line with the above view, humanistic psychologists and positive psychologists believe that humans have positive origin traits. Maslow (Goble, 2014) revealed that 
positive human origin traits include virtue, simplicity, integrity, and various other positive qualities. McCrae \& Costa (2003) described the right conditions in terms of agreeableness personality. Agreeableness personality is characterized by tender-mindedness (caring for other people's circumstances), modesty (humility and straightforwardness), compliance (being friendly), altruism (being generous and having a desire to help) (Reimers \& Oakley, 2016), straightforwardness (sincere in stating something), and trust (trust in others).

Fifth: The effect of positive parenting on religiosity. Even though humans are religious, the process of nurturing and education that they undergo does not always lead them to become religious persons. According to Najati (1985), in the course of their lives, humans are faced with various tribulations that make them forget or no longer uphold the primordial covenant they had with Allah. Humans do not remember that they once vowed that Allah is their God.

The Holy Prophet indicated that in the beginning, humans were born in a state of fitrah (sure and obedient to Allah), but the nurturing process that they lived could turn them into unbelievers by making them Christian, majesty, or Jewish. The point is humans can change (Tajab, Madjid, \& Hidayati, 2019). Islam views parents as holders of God's mandate to educate and care for their children. Parents are instructed to set an example for their children, teach the basics of religion, instil ethical moral values (Loudová \& Lašek, 2015), guide children in interacting with others, and even with other creatures. In essence, parents are instructed to be fully involved in children's education, especially education relating to character.

The above view has the support of Juhari's research (2010) that what parents do will be imitated by their children. Parents who diligently worship and give messages about the importance of worship will make their children grow in religiosity. Daradjat (1997) revealed that the behavior exhibited by parents would be seen by children as a reference. The results show that children's behavior was influenced by their vision (83\%), hearing (11\%), and smell (6\%).

Sixth: The effect of positive parenting on agreeableness personality. Personality is a stable characteristic and a long-lasting pattern in which a person thinks, feels, and behaves. Personality is formed from two main factors, namely heredity and environmental factors. Heredity is a factor whereby inherited genes determine a person's character and physiological development. Meanwhile, environmental factors are factors that originate from the environment in which individuals were raised (Edobor \& Ekechukwu, 2015).

Environmental factors that affect a person's personality consist of three domains, according to the Tri Education Center, namely family, school, and community. This factor has a big enough share for someone's development, i.e. $50 \%$ or more personality is formed from environmental factors (Cervone \& Pervin, 2013). The family is part of environmental factors that play an essential role in shaping one's personality $(\mathrm{Oz}, 2014)$. The reason is that family is the place of first interaction since the child was born, so that the family has a longer-term impact on the development of one's personality formation (Mullins, 2005).

Each person is generally raised in a family consisting of a mother and a father as parents. In the process of a child growing up, parents have the responsibility to care for and raise them properly. The success of parenting can be seen from the personality of the child as an adult (Edobor \& Ekechukwu, 2015). The child's personality that emerges as an adult reflects the type of care a child received. It reflects the methods used by parents in educating and raising children under their care (Levine, 2003). The particular method used by parents will ultimately affect the specific personality of the foster child.

Children who experience positive parenting will develop with positive personality traits. Through positive parenting, parents do care with full support. One positive development is to make children have an agreeableness personality. The nature of agreeableness personality is a personality that is described in individuals who are friendly, pleasant, tolerant, helpful, trusting, forgiving, caring, and tend to be cooperative (Bowling \& Eschleman, 2010).

Agreeableness is one of the traits found in the Big Five Personality (Puryear, 2019). Parents who receive positive care will develop it with agreeableness and will apply it to the role of the parent relay (Schofield, Conger, Donnellan, Jochem, Widaman, \& Conger, 2012). It is necessary because children tend to imitate 
the behavior of parents as role models. When a child mimics the positive parenting of parents, the child grows up with a positive character also (Edobor \& Ekechukwu, 2015). The role will eventually settle into the child as a personality.

\section{CONCLUSION}

The findings of this study are a theoretical model of the influence of positive parenting and agreeableness towards parental engagement in children's character education through mediators of religiosity following the realities of life. Thus, it can be concluded that the main findings of this study are that parental engagement in character education is not only influenced by positive parenting but is also influenced by the nature of agreeableness by optimizing the mediator variable, namely religiosity. Positive parenting has direct effects, and indirect effects through the mediator of religiosity, both of which affect parental engagement. Religiosity and positive parenting directly influence the engagement of parents in children's character education. The indirect effect of parental engagement in character education is an agreeableness personality variable. Agreeableness will only affect the engagement through the mediator of religiosity.

Future research will need to examine how engagement is different levels of education besides primary schools, ranging from kindergartens, junior high schools senior high schools to college. Morover, at the level of primary education, need to activate the functions of the school committee and parents' groups. Then, good synergy will occur between the school and parents to produce more optimal results of character education process.

\section{REFERENCES}

Aghababaei, N. (2014). God, the good life, and HEXACO: The relations among religion, subjective well-being and personality. Mental Health Religion \& Culture, 17(3), 284-290. https://doi.org/10.1080/136746 76.2013.797956.

Ahmedi, V. (2019). Teachers' attitudes and practices towards formative assessment in primary schools. Journal of Social Studies Education Research, 10(3), 161-175. https://jsser.org/index.php/jsser/article/ view/1233.
Ancok, D., \& Nashori, F. (2000). Psikologi islami: Solusi Islam atas problem-problem psikologi. [Islamic psychology: Islamic solutions to psychological problems]. Yogyakarta, Indonesia: Pustaka Pelajar.

Aziz, S. A. (2015). Fitrah criticism: An islamic psychological approach. Journal of Islamic Studies, Prince of Songkla University, 6(1), 1-10. https://so03. tci-thaijo.org/index.php/JOIS/article/ download/140196/103962/.

Bouakaz, L., \& Persson, S. (2007). What hinders and what motivates parents' engagement in school? International Journal about Parents in Education, 1(0), 97-107. http:// muep.mau.se/handle/2043/15232.

Bowling, N., \& Eschleman, K. (2010). Employee personality as a moderator of the relationship between work stressors and counterproductive work behavior. Journal of Occupational Health Psychology, 15(1), 91-103. https://doi.org/10.1037/ a0017326.

Cervone, D., \& Pervin, L. (2013). Personality: Theory and research. New York, NY: Wiley and Sons.

Cheng, H., Green, A., Chapman, B. P., Treglown, L., \& Furnham, A. (2017). Educational achievement and traits emotional stability and agreeableness as predictors of the occurrence of backache in adulthood. Personality and Individual Differences, 117, 205-209. https://doi.org/10.1016/j. paid.2017.06.008.

Costa, P., \& McCrae, R. R. (1997). Longitudinal stability of adult personality. In R. Hogan, J. Johnson, \& S. Briggs (Eds.). Handbook of personality psychology. San Diego, CA: Academic Press, pp. 269-290. https://doi. org/10.1016/B978-012134645-4/500123.

Decker, K., Thruston, I., Howell, K., Hasselle, A., \& Kamody, R. (2021). Association between profiles of maternal strengths and positive parenting practices among mother experiencing adversity. Science and Practice, 21(1), 1-23. https://doi.org/ 10.1080/15295192.2020.1729611. 
Daradjat, Z. (1997). Ilmu jiwa dan agama. [Psychology and religion]. Jakarta, Indonesia: Bulan Bintang.

Diana, R. R., Chirzin, M., \& Bashori, K. (2019, 25-27 June). Character problems of elementary students and parental engagement in schools. Paper presented at 1st Annual International Conference on Social Sciences and Humanities, Yogyakarta, Indonesia. https://doi. org/10.2991/aicosh-19.2019.46.

Edobor, O. J., \& Ekechukwu, R. (2015). Parenting styles and personality traits among senior secondary school students in rivers state Nigeria, West African. British Journal of Psychology Research, 3(4), 9-18. https:// www.eajournals.org/journals/britishjournal-of-psychology-research-bjpr/ vol-3-issue-4-october-2015/parentingstyles-and-personality-traits-amongsenior-secondary-school-students-inrivers-state-nigeria-west-african/.

El-Hilali, N., \& Al-Rashidi, L. (2015). The impact of parental involvement, personality trait, and organizational support on satisfaction. Social and Behavioral Sciences, 177, 408-419. https://doi.org/10.1016/j. sbspro.2015.02.382.

Eysenck, M., W. (1998). Personality and the psychology of religion. Mental Health, Religion, \& Culture, 1(1), 11-19. https:// doi.org/10.1080/13674679808406493.

Ferrari, J., R. (2017). Called and formed: Personality dimensions and leadership styles among catholic deacons and men in formation. Pastoral Psychology, 66(2), 225-237. http://doi.org/10.1007/s11089016-0741-1.

Forza, C., \& Filippini, R. (1998). Tqm impact on quality conformance and customer satisfaction: a causal model. International Journal of Production Economics, 55(1), 1-20. https://doi.org/10.1016/S09255273(98)00007-3.

Fox, S., \& Olsen, A. (2014). Defining parental engagement. Canberra, Australia: ARACY (Australian Research Alliance for Chlidren and Youth).
Furr, R. M., \& Bacharach, V. R. (2013). Psychometrics: An introduction ( $\left.2^{\text {nd }} \mathrm{ed}\right)$. Thousand Oaks, CA: SAGE Publications.

Ghazali, I. A. (2017). Model Persamaan Struktural. Konsep dan aplikasi dengan Program AMOS 19.0. [Structural Equation Model. Concepts and applications with the AMOS 19.0 Program]. Semarang, Indoesia: Badan Penerbit Universitas Diponegoro.

Goble, F. G. (2014). The third force, the psychology of Abraham Maslow. (A. Supratiknya, Trans) Yogyakarta, Indonesia: Kanisius. (Original work published 1970).

Guo, S. (2018). A model of religious involvement, family processes, selfcontrol, and juvenile delinquency in twoparent families. Journal of Adolescence, 63, 175-190. https://doi.org/10.1016/j. adolescence.2017.12.015.

Hu, L.-T., \& Bentler, P. M. (1995). Evaluating model fit. In R. H. Hoyle (Ed.). Structural equation modeling: Concepts, issues, and applications. Thousand Oaks, CA: Sage Publications, pp. 76-99.

Huver, R. M. E., Otten, R., Vries, H. D., \& Engels, R. C. M. E. (2010). Personality and parenting style in parents of adolescents. Journal of Adolescence, 33(3), 395-402. https://doi.org/10.1016/j. adolescence.2009.07.012.

Jalaluddin, J. (2008). Psikologi agama. [Psychology of religion]. Jakarta, Indonesia: Raja Grafindo Persada.

Juffer, F., Bakermans-Kranenburg, M. J., \& van IJzendoorn, M. H. (2017). Pairing attachment theory and social learning theory in video-feedback intervention to promote positive parenting. Current Opinion in Psychology, 15, 189-194. https://doi.org/10.1016/j. copsyc.2017.03.012.

Juhari, R., Yaacob, S. N., \& Talib, M. A. (2010). Correlates of father engagement amongst muslim father in Malaysia. International 
Journal of Social Policy and Society, 7, 90-103.

Khoynezhad, G., Rajaei, A., R., \& Sarvarazemy, A. (2012). Basic religious beliefs and personality traits. Iranian Journal of Psychiatry, 7(2), 82-86. https://ijps.tums. ac.ir/index.php/ijps/article/view/209.

Kline, R. B. (2015). Principle and practice of Structual Equation Modeling. New York, NY: Guilford Press.

Komalasari, M. D., \& Pardjono. (2015). Integrated Lkpd development for developing the character values of responsibilit discipline and achievement. Jurnal Pendidikan Karakter, 5(1), 36-47. https://doi.org/10.21831/jpk.v0i1.8611.

LaCroix, A. (2014). Reading motivation, parent engagement, and student engagement as it relates to reading achievement of urban adolescents (Doctoral Dissertation, St. John Fisher College). http://fisherpub.sjfc. edu/education_etd/204.

Leathers, S. J., Spielfogel, J. E., Geiger, J., Barnett, J., \& Voort, B. L. V. (2019). Placement disruption in foster care: Children's behavior, foster parent support, and parenting experiences. Child Abuse and Neglect, 91, 147-159. https://doi. org/10.1016/j.chiabu.2019.03.012.

Levine, J. (2003). Know your parenting personality: How to use the enneagram to become the best parent you can be. New York, NY: Wiley.

Loudová, I., \& Lašek, J. (2015). Parenting Style and its influence on the personal and moral development of the Child. Procedia - Social and Behavioral Sciences, 174, 1247-1254. https://doi.org/10.1016/j. sbspro.2015.01.744.

McCrae, R. R., \& Costa, P. T., J. (2003). Personality in adulthood: Five-factor theory perspective. New York, NY: The Guildford Press.

Meyer, J., Fleckenstein, J., Retelsdorf, J., \& Köller, O. (2019). The relationship of personality traits and different measures of domain-specific achievement in upper secondary education. Learning and Individual Differences, 69, 45-59. https:// doi.org/10.1016/j.lindif.2018.11.005.

Meyers, D. C., Domitrovich, C. E., Dissi, R., Trejo, J., \& Greenberg, M. T. (2019). Supporting systemic social and emotional learning with a schoolwide implementation model. Evaluation and Program Planning, 73, 53-61. https://doi. org/10.1016/j.evalprogplan.2018.11.005.

Manzon, M., Miller, R., Hong, H., \& Khong, L. (2015). Parent engagement in education. Singapore: NIE (National Institute of Education).

Monks, F. J., Knoers, A. M. P., \& Haditono, S. R. (2014). Psikologi perkembangan: Pengantar dalam berbagai bagiannya. [Developmental psychology: An introduction to its various sections.]. Yogyakarta, Indonesia: Gadjah Mada University Press.

Mullins, L. J. (2005). Management and organizational behavior. London: FT Pitman.

Munir, A., \& Malik, J. (2020). Mediating role of religious orientation and moral character for the relationship between parent and peer attachment and delinquency. Cogent Psychology, 7(1), 1-15. https://doi.org/10 $.1080 / 23311908.2020 .1761042$.

Muwaga, M., Nashori, F., \& Sholeh, A. (2020). The impact of social environment on the sexual self-segulation of university students in Uganda. International Journal of Islamic Educational Psychology, 1(2), 75-88. https://doi.org/10.18196/ijiep. v1i2.10011.

Najati, M. U. (1985). Al-Qur'an dan ilmu jiwa. [The Qur'an and the science of the soul]. Bandung, Indonesia: Pustaka.

Nashori, F. (2010). Mengantar anak meraih prestasi: panduan praktis melejitkan potensi anak. [Leading children to achievement: A practical guide to boosting 
children's potential]. Yogyakarta, Indonesia: Pustaka Fahima.

Oz, H. (2014). Big five personality traits and willingness to communicate among foreign language learners In Turkey. Social Behavior and Personality, 42(9), 1473-1482. https://doi.org/10.2224/ sbp.2014.42.9.1473.

Papalia, D., Olds, S. W., \& Fieldman, R. D. (2008). Human development. New York, NY: The McGraw Hill Companies.

Perez-Albeniz, A., \& de Paul, J. (2004). Gender differences in empathy in parents at high- and low-risk of child physical abuse. Child Abuse and Neglect, 28(3), 289-300. https://doi.org/10.1016/j. chiabu.2003.11.017.

Puryear, J. S. (2019). Personality: Big five personality characteristics. In S. Pritzker \& M. Runco (Eds.). Reference module in neuroscience and biobehavioral psychology. Oxford, UK: Academic Press, pp. 316-321. https://doi.org/10.1016/ B978-0-12-809324-5.23700-0.

Reimers, M., \& Oakley, B. (2016). Empathy, theory of mind, cognition, morality, and altruism. In M. Tibayrenc \& F. J. Ayala (Eds.). On human nature: Biology, psychology, ethics, politics, and religion. Oxford, UK: Academic Press, pp. 355363. https://doi.org/10.1016/B978-0-12420190-3.00021-1.

Saroglou, V. (2002). Religion and the five factors of personality: A meta-analytic review. Personality and Individual Differences, 32(1), 15-25. https://doi.org/10.1016/ S0191-8869(00)00233-6.

Saroglou, V., \& Fiasse, L. (2003). Birth order, personality, and religion: A study among young adults from a three-sibling family. Personality and Individual Differences, 35(1), 19-29. https://doi.org/10.1016/ S0191-8869(02)00137-X.

Saxena, R., \& Saxena, S. K. (2020). Preparing children for pandemics. In Saxena S. (Ed.). Coronavirus disease 2019 (COVID-19).
Singapore: Springer, pp. 187-198. https:// doi.org/10.1007/978-981-15-4814-7_15.

Schneider, C., \& Arnot, M. (2018). Transactional school-home-school communication: Addressing the mismatches between migrant parents' and teachers' views of parental knowledge, engagement and the barriers to engagement. Teaching and Teacher Education, 75, 10-20. https://doi. org/10.1016/j.tate.2018.05.005.

Schofield, T. J., Conger, R. D., Donnellan, M. B., Jochem, R., Widaman, K. F., \& Conger, K. J. (2012). Parent personality and positive parenting as predictors of positive adolescent personality development over time. Merrill-Palmer Quarterly, 58(2), 255-283. https://doi.org/10.1353/ mpq.2012.0008.

Setiono, K. (2011). Psikologi keluarga. [Family psychology]. Bandung, Indoesia: PT Alumni.

Setoh, P., Santos, R., Zhao, S., Zhang, L., Heyman, G., \& Lee, K. (2020). Parents with greater religiosity lie less to their children. Psychology of Religion and Spirituality. $\quad$ https://doi.org/10.1037/ rel0000377.

Shihab, Q. (1996). Wawasan Al-Quran. [Quranic insights]. Bandung, Indonesia: Mizan.

Shodiq, S. F., Syamsudin, Madjid, A., \& Alam, N. A. R. (2019). Towards better management of private education in Indonesia: Lessons learned from Muhammadiyah schools. Jurnal Humanities and Social Sciences Reviews, 7(2), 146-155. https://doi.org/ https://doi.org/10.18510/hssr.2019.7215.

Sokip, S., Akhyak, A., Soim, S., Tanzeh, A., \& Kojin, K. (2019). Character building in islamic society: A case study of muslim families in Tulungagung, East Java, Indonesia. Journal of Social Studies Educational Research, 10(2), 224-242. https://jsser.org/index.php/jsser/article/ view/906.

Sukendar, A., Usman, H., \& Jabar, C. S. A. (2019). Teaching-loving-caring (asah- 
asih-asuh) and semi-military education on character education management. Cakrawala Pendidikan, 38(2), 292-304. https://doi.org/10.21831/cp.v38i2.24452.

Suriansyah, A., \& Aslamiah, A. (2015). Strategi kepemimpinan kepala sekolah, guru, orang tua, dan masyarakat dalam membantuk karakter siswa. [The leadership strategies of school principals, teachers, parents, and the communities in building the students' character]. Cakrawala Pendidikan, 34(2), 234-247. https://doi.org/10.21831/ cp.v2i2.4828.

Suud, F. M. \& Subandi, S. (2017). Kejujuran dalam perspektif psikologi islam: Kajian konsep dan empiris. Jurnal Psikologi Islam, 4(2), 121-134. https://jpi.apihimpsi.org/index.php/jpi/article/view/44/.

Suud, F. M., Madjid, A., \& Sutrisno. (2019). The study of educational honesty stages implementation in an Indonesian school. Humanities \& Social Sciences Reviews, 7(4), 502-510. https://doi.org/https://doi. org/10.18510/hssr.2019.7467.

Suud, F. M., Chaer, M. C., \& Setiawan, W. (2020). Implementation educational psychology theories at traditional boarding school in Aceh. Journal of Critical Reviews, 7(9), 371-377. https://doi.org/10.31838/ jcr.07.09.78.

Szcześniak, M., Sopińska, B., \& Kroplewski, Z. (2019). Big five personality traits and life satisfaction: The mediating role of religiosity. Religions, 10(7), 1-16. https:// doi.org/10.3390/rel10070437.

Tajab, M., Madjid, A., \& Hidayati, M. (2019). Psychology of patience in Al-Misbah Exegeis. Humanities \& Social Sciences Reviews, 7(5), 1221-1230. https://doi.org/ https://doi.org/10.18510/hssr.2019.75161.
.Weaver, N. L., Weaver, T. L., Loux, T., Jupka, K. A., Lew, D., \& Sallee, H. (2019). The impact of RISE Up! In promoting positive parenting and safety behaviors of parents with young children. Children and Youth Services Review, 105, 104422. https://doi. org/10.1016/j.childyouth.2019.104422.

Weiss, H. B., Kreider, H., Lopez, M. E., \& Chatman-Nelson, C. (Eds.). (2010). Preparing educators to engage families: Case studies using an ecological systems framework ( $\left.2^{\text {nd }} \mathrm{ed}\right)$. Thousand Oaks, CA: Sage Publications.

Wong, R. S. M., Ho, F. K. W., Wong, W. H. S., Tung, K. T. S., Chow, C. B., Rao, N., ... \& Ip, P. (2018). Parental Involvement in primary school education: its relationship with children's academic performance and psychosocial competence through engaging children with school. Journal of Child and Family Studies, 27(5), 15441555. https://doi.org/10.1007/s10826017-1011-2.

Wuryandani, W., Maftuh, B., Sapriya, S., \& Budimansyah, D. (2014). Pendidikan karakter disiplin di sekolah dasar. [Discipline character education in elementary school]. Cakrawala Pendidikan, 33(2), 286-295. https://doi. org/10.21831/cp.v2i2.2168.

Yamamoto, E., Matsuda, G., Nagata, K., Dan, N., \& Hiraki, K. (2019). Subtle temporal delays of mothers' responses affect imitation learning in children: Mother-child interaction study. Journal of Experimental Child Psychology, 179, 126-142. https://doi.org/10.1016/j. jecp.2018.10.010. 
Appendix 1. Parent Engegement Scale

\begin{tabular}{|c|c|c|}
\hline No. Aspect & Indicator & $\begin{array}{l}\text { Number of } \\
\text { Item }\end{array}$ \\
\hline \multirow{2}{*}{$\begin{array}{l}\text { 1. High expectations and } \\
\text { aspirations for children }\end{array}$} & Giving children confidence to make their own choices & 1,36 \\
\hline & Provide support to children & $3,11,16$ \\
\hline \multirow[t]{2}{*}{ 2. Parent-child conversation } & Positive communication & $2,4,8$ \\
\hline & Open communication & $5,7,14,9$ \\
\hline \multirow{2}{*}{$\begin{array}{l}\text { 3. Positive environment for } \\
\text { homework }\end{array}$} & Instilling independence and responsibility for learning & 14 \\
\hline & $\begin{array}{l}\text { Provide a comfortable environment both physically and } \\
\text { psychologically }\end{array}$ & $6,25,27$ \\
\hline \multirow{2}{*}{$\begin{array}{l}\text { 4. Cognitively stimulating } \\
\text { environment }\end{array}$} & Provide learning facilities at home & 12,18 \\
\hline & Enrich children's knowledge & 10,26 \\
\hline \multirow{2}{*}{$\begin{array}{l}\text { 5. Support for children's } \\
\text { social and emotional } \\
\text { wellbeing }\end{array}$} & $\begin{array}{l}\text { Ensuring children have positive interactions with the } \\
\text { teacher }\end{array}$ & 19,28 \\
\hline & Make sure the child has fun friends at school & $29,31,32$ \\
\hline \multirow{2}{*}{$\begin{array}{l}\text { 6. Parent-teacher } \\
\text { communication }\end{array}$} & periodic communication between teachers and parents & $17,20,30$ \\
\hline & Mutuall trust between teachers and parents. & $15,23,34$ \\
\hline \multirow{2}{*}{$\begin{array}{l}\text { 7. Engagement in the school } \\
\text { community }\end{array}$} & Attending school event & $22,24,35$ \\
\hline & Parents' contribution in supporting school programs & 21,33 \\
\hline \multicolumn{2}{|l|}{ Total } & 36 \\
\hline
\end{tabular}

Appendix 2. Religiosity Scale

\begin{tabular}{lll}
\hline No. Dimensions & Indicators & $\begin{array}{l}\text { Number of } \\
\text { Items }\end{array}$ \\
\hline
\end{tabular}

1. Aqidah Have faith in Allah SWT, belief the existence of angels, the holy 1,2, 3, 4 book of Al-Qur'an, Rasool Allah, doomsday, and qadha qadar.

2. Ritual Prayers, fasting, hajj, zakat, reading the holyAl- Qur'an, dzikir. 5, 6, 7, 8, 9, 10,11

3. Moral Helping others, disciplining or obeying applicable regulations, 12, 13, 14, being serious in working, choosing halal, honest, trustworthy, 15, 16, 17, respectful of people, istiqomah. 18,19

4. Ihsan Feelings close to Allah, feelings of pleasure in carrying out 20,21, 22, $\begin{array}{ll}\text { worship, feelings of gratitude } 23,24,25 & 22,21,22\end{array}$

5. Knowledge Knowldge of aqidah $\quad 1,2,3,4,5$

Knowldge of worship $\quad 6,7$

Knowldge of morals $\quad 8,9,10,11$

Total 
Appendix 3. Positive Parenting Scale

\begin{tabular}{lll}
\hline No. Aspects & Indicators & $\begin{array}{l}\text { Number of } \\
\text { Items }\end{array}$ \\
\hline 1. Attachment & Forming future parent-child relationships & 6 \\
& Understand each other's feelings & 9,28 \\
& Provide support & $2,14,21$ \\
2. Respect & Wise to child & 3,17 \\
& Respect for Children & 11 \\
& Parents provide space for child to develop themselves & $10,27,33$ \\
3. Proactive & Provide time to talk together & $12,23,31$ \\
& Responsive & 30 \\
4. Emphatetic & Assisting children in learning & $13,22,34$ \\
& Understanding the need of children & $2,20,29$ \\
& Empathy & $5,29,25$ \\
5. Discipline & Parents give freedom to children with supervision & $7,18,32$ \\
& Controlling children's behavior & $4,15,26$ \\
& Teach new skills & 16 \\
& Helping children to be able to correct mistakes and find & 1,8 \\
\hline Total & solutions & \\
\hline
\end{tabular}

Appendix 4. Agreeableness Personality Scale

\begin{tabular}{lll}
\hline No. Aspects & Indicators & $\begin{array}{l}\text { Number of } \\
\text { Items }\end{array}$ \\
\hline 1. Tender-mindedness & $\begin{array}{l}\text { Empathy for what other people feel, good listeners for } 1,2 \\
\text { others }\end{array}$ \\
5. Straight-forwardness & $\begin{array}{l}\text { Geat commitment to others, there is openness in } \\
\text { establishing communication with others }\end{array}$ \\
\hline Total & & $\mathbf{3}$ \\
\hline
\end{tabular}

